\title{
The Structural Damages After Nepal Earthquakes
}

\author{
İbrahim Baran KARAŞİN ${ }^{1}$, Dursun BAKIR ${ }^{2}$, Mustafa ÜLKER ${ }^{3}$, Ali Emre \\ $\mathrm{ULU}^{4}$

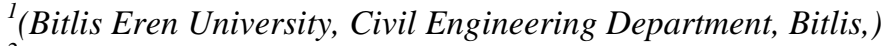 \\ ${ }^{2}$ (Bitlis Eren University, Civil Engineering Department, Bitlis,)
}

\begin{abstract}
Two destructive earthquakes happened on April 25 and May 12 in Nepal. These earthquakes have been ranked among the most significant ones due to their effects. The earthquakes were felt in many settlements. Nepal earthquakes caused considerable damage to buildings and to public facilities. The first damage assessment of constructions after earthquake has importance in order to prevent loss of life and property in coming earthquakes. In this study the effects of earthquakes on constructions in Nepal have been evaluated. The damages to reinforced-concrete (RC) and masonry structures after earthquake are evaluated and recommendations made in Nepal which is seismically active. The goal of this paper is to introduce major reasons for structural damages after earthquakes. The observed damages overlap with typical earthquake damages. It has been observed that the negative features of constructions have caused an increase in damage extent. The careless selection of the design and construction of structural systems has increased the damage extent.
\end{abstract}

Keywords: Nepal earthquake, masonry, reinforced concrete, structural damages

\section{INTRODUCTION}

In general terms, risk can be defined as the combination of probability of occurrence and the consequence of a specified hazardous event. Otherwise, the value of risk depends on the severity of hazard and the vulnerability of the elements that will be affected by the hazardous event [1]. The precision of urban and rural building stocks will enhance earthquake damages. The earthquakes magnitude and the negative constitutive properties will reveal an increase in the amount of damage. In order to provide more significant approaches to diminish the level of damage risk which occurs after earthquakes, it will be suggested to know about the buildings' properties which have been impressed in the buildings' seismic behaviour under earthquakes [2].

One of ancient civilizations over world can be seen in Nepal. The earliest inscription found in Kathmandu Valley within the World Heritage Site of the Changunarayan area dates back to 425 AD. The town of Bhaktapur, one of the three main settlements of the valley, is said to have been established in the 9th century AD. A rich tradition of story-telling is seen in Nepal and many family trees and especially rulers describe historical events. Flummoxed, references related to damage which are made by historical earthquakes are rarely found in these writings and inscriptions [3]. In this study the effects of earthquakes on constructions in Nepal was evaluated. The damage to reinforced-concrete (RC) and masonry structures after earthquakes are evaluated and recommendations made. Based on the post-earthquake technical inspections, the goal of this paper is to introduce major reasons for structural damages in the disaster area. Some remarkable lessons learned from earthquake-induced failures and damages specific to building construction techniques are presented in this paper.

\section{EARTHQUAKES IN NEPAL}

Nepal has got an activated seismic belt. Many destructive earthquakes have been seen in its history. It is believed that Nepal has got the earthquake risk which would be one of highest in the world [4].

Nepal and the all Himalayan region at the border of China were formed as a result of the collision of the Indian plate with the Tibetan plate about 50 million years ago. This plate activity continues which results in subduction of Indian plate below the Tibetan plate, making Nepal and the entire Himalayan region seismically active. Major past earthquakes have occurred in Nepal were given in Table 1. [5], [6], [7], [8], [9]. Past earthquake evidence indicates that Nepal had experienced two major earthquakes in the last century. In 1934 and 1988 of magnitude 8.4 and 6.5 resulted in more fatalities and highly affected the building structures in the Kathmandu valley [10].

Table 1. Major earthquakes that occurred in Nepal

\begin{tabular}{|c|c|c|c|c|c|c|}
\hline No & Date & Place & Lat. $\left({ }^{\circ}\right)$ & Lan. $\left({ }^{\circ}\right)$ & Fatalities & Magnitude \\
\hline 1 & 7.6 .1255 & Kathmandu & 27,70 & 85.30 & $30 \%$ pop & N/A \\
\hline
\end{tabular}


The Structural Damages after Nepal Earthquakes

\begin{tabular}{|c|c|c|c|c|c|c|}
2 & 26.8 .1833 & Kathmandu -Bihar & 28.30 & 85.50 & 6.500 & 8.0 \\
\hline 3 & 7.7 .1869 & Kathmandu & 27.70 & 85.30 & 750 & 6.5 \\
\hline 4 & 28.8 .1916 & Nepal-Tibet & 30.0 & 81.0 & 3500 & 7.7 \\
\hline 5 & 15.1 .1934 & Nepal-Tibet & 26.77 & 86.76 & 10.600 & 8.0 \\
\hline 6 & 27.6 .1966 & Nepal - India border & 29.55 & 80.85 & 80 & 6.3 \\
\hline 7 & 29.7 .1980 & Nepal -Pithoragarh -India & 29.59 & 81.11 & 200 & 6.5 \\
\hline 8 & 20.8 .1988 & Kathmandu -Bihar - India & 26.77 & 86.62 & 1,091 & 6.6 \\
\hline 9 & 18.9 .2011 & Sikkim & 27.33 & 88.62 & 111 & 6.8 \\
\hline 10 & 25.4 .2015 & Kathmandu - Tibet & 28.15 & 84.71 & 9,000 & 7.8 \\
\hline 11 & 12.5 .2015 & Chinalkha - Dolakha & 27.97 & 85.96 & 213 & 7.3 \\
\hline
\end{tabular}

Two destructive earthquakes happened on April 25th and May 12th, 2015 in Nepal. These earthquakes have been ranked among the most significant ones due to their effects. The earthquakes were felt in many settlements. Maximum structural losses observed in Sindulpalchowk, Kathmandu, Nuwakot, Dhading, Rasuwa, Gorkha, Kavrepalanchowk, Bhaktapur, Lalitpur, Dolakha, Makawanpur, Ramechhap, Sindhuli, and Lamjung. As a result of thrust faulting which is on or near to the main thrust interface that is between the India plate which is the sub ducting and Eurasia plate which is other overriding one to north, it has occurred. The India plate is convex with Eurasia at a rate of $45 \mathrm{~mm} / \mathrm{yr}$ towards the Northwest as a fraction of which $(\sim 18 \mathrm{~mm} / \mathrm{yr})$ is driving Himalayan moutain range's uplift, at this earthquake's epicentral area which is approximately $80 \mathrm{~km}$ to the Northwest of the Nepalese capital of Kathmandu. The first location, size and focal mechanism which belong to April 25 earthquake tie in its occurrence on the decollement that is related to the Main Himalayan Thrust, which identifies the subduction thrust interface between the India and Eurasia plates [11].

The hypocenter of the Mw 7.3 earthquake on May 12, 2015 was located around 80 kilometres northeast of Kathmanduat 10 kilometres depth. The rupture plane strikes parallel to the Himalayan Belt WNW to ESE, dips with $10^{\circ}$ to the North and extends about $60 \mathrm{~km}$ along the strike and $20 \mathrm{~km}$ perpendicular to it. The maximum PGA was estimated at 0.4g. [11]. Almost 300,000 houses were destroyed. Sindulpalchowk, Kathmandu, Nuwakot, Dhading, Rasuwa, Gorkha, Kavrepalanchowk, Bhaktapur, Lalitpur, Dolakha, Makawanpur, Ramechhap, Sindhuli, and Lamjung districts were most affected. [12] (Fig. 1).

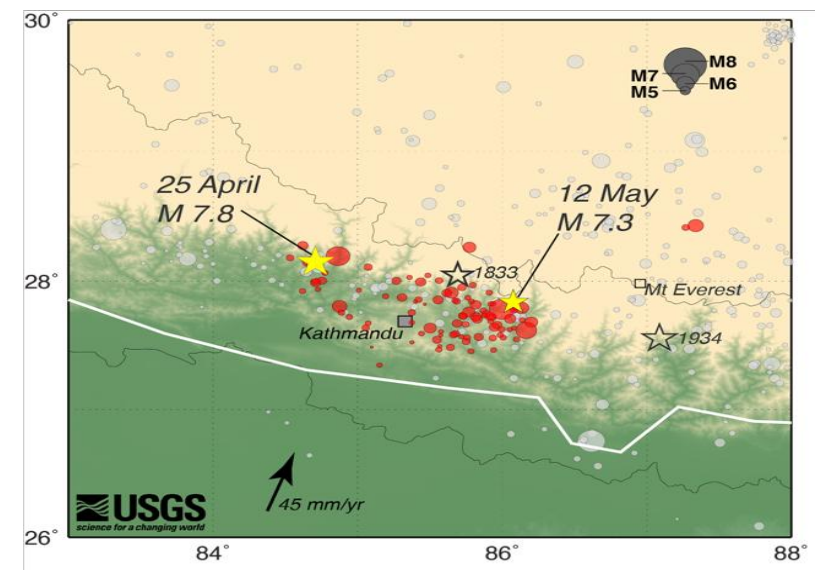

Figure 1. Earthquakes in Nepal [12]

\section{STRUCTURAL PROPERTIES AND DAMAGES IN NEPAL}

Especially in recent years, destructive earthquakes have occurred in the world and then the importance of studies; researches and prevention which are related to earthquake have increased. Earthquake damage will go up by urban building stocks' precision. The negative structural features will increase the size of hazard [13]. Structural damages that occurred after earthquakes show that the majority of the existing building stocks in the world do not have enough safety.The damages to reinforced-concrete (RC) and masonry structures after earthquakes were evaluated and recommendations made in Nepal which is seismically active. Construction materials for buildings fall into two groups: traditional and modern materials in Nepal. Traditional materials such as earth, stone, timber and bamboo are naturally occurring, and are used with very limited processing or quality grading. These types of buildings, mostly constructed out of municipal areas, tend to be beyond the control of urban building regulations and planning requirements. Cement and steel bars are the modern materials [14]. 


\section{1. $\quad$ STRUCTURAL PROPERTIES OF RC BUILDINGS}

Reinforced concrete building construction has started in Nepal since the late of 1970s. As reinforced concrete construction replaces other construction materials and solutions such as adobe, stone and brick masonry in Kathmandu Valley as well as in the country's other parts, reinforced concrete building construction increase rapidly in the last decades. Most of the buildings which are in Nepal's urban areas have 2-6 storeys which were up built by light reinforced frames with infill masonry panels which might have inadequate capacity and can require a ducting detailing and which were defectively up built and may have restricted endurance conditions, because there were building practices which depended on the inferior masonry quality, lean frames and lack of reinforcement [5], [15].

The kind of building is generally up built in Nepal's urban and semi-urban areas. It has got all of characteristics which belong to a traditional building, only as it does not include that several construction materials are not local. It is one of the most emerging building typologies in Nepal. Mostly, it is non-engineered building typology. Yet, the durable structural engineers are also involved sometimes in the design in urban areas. A lightly reinforced frame is up built first in this building type and then infill walls are uplifted later between columns. These buildings are highly nondurable to earthquake as they have deficit detailing, inferior construction materials and the insufficient technology which are used. This building type is seen as it is the safety and the strongest at all points when it is compared with all of the other building types in Nepal. Walls and frame are not integrated. The infills are not tied to the frames [16]. In reality, most of the structures are potentially seismically vulnerable due to the non-engineered construction [10]. The technicians have been designed majority of the buildings in Kathmandu. The seismic design rules were not considered in many cases in these buildings [17].

\subsection{PROPERTIES OF MASONRY BUILDINGS IN NEPAL}

The history of masonry structures is as old as the history of human beings. Most of these structures have not taken engineering services. These structures have not provided the principles of design under an earthquake. The dominant building type consists of adobe and stone masonry buildings in rural areas. The reason of choosing such construction materials is that they are easily available and they are more economical when compared with reinforced concrete.

In Nepal, there are two types of non-engineered brick masonry buildings, i.e. unconfined brick masonry buildings and reinforced concrete buildings with brick masonry infill. Although Nepal Building Code becomes mandatory, limited improvements are observed in many of the buildings, constructed without considering the proper detailing [5]. The column sections resulting from a design based on the NBC code are insufficient to withstand the expected earthquake demands. Beam-column joints are not properly detailed [5].The prevalent durable building types are rubber /field stone masonry and unreinforced brick masonry construction. Generally, it is rectangular plan shape and it is developed over three storeys. These buildings' most interesting characteristic which is from an architectural and also seismic point of view is the timber frame's existing. Generally, at ground floor on the facade which is to give an open space for workshops or shops. Especially found in Kathmandu, Lalitpur and Bhaktapur's royal cities, there may be some examples in smaller towns and village of the Kathmandu Valley too. The vertical load-resisting system is un-reinforced masonry walls.

Brick compounded with mud mortal which forms ordinary masonry. Typically, there were two types of bricks; first one in ordinary sun-dried bricks with dimensions $210 \times 105 \times 50 \mathrm{~mm}$ and the second one is fired bricks which are called as "dachi aapa" which has got the same dimensions but which are in the shape of a trapezoidal cross section so that mud bed-joint is partially taken up exteriorly by the brick. This type of construction is not authorized as per development control rules and a non-engineered [18].

Stone masonry kind can be found in Nepal also. This type of structures was most extensively constructed throughout the foothills, hills and mountains. This kind of construction is generally found in rural and urban areas. This structure type has been used in practice for more than 200 years. Stone masonry walls are the vertical load-resisting system. Stone masonry walls are carried loadbearing walls. The gravity loads of the building are carried by these walls. Wood planks and joists covered with thick mud overlay. Floor and roof structures are loose fit structure, with one component stacked atop the other without any nailing, and should be considered as a flexible diaphragm. Binding mortar for walls is mud mortar or there is no binding material at all (dry stone masonry); Stone units (boulders) are irregular; Absence of header stones at wall junctions and corners [19].

\subsection{DAMAGES TO MASONRY BUILDINGS IN NEPAL}

In villages, the dominant building type consists of adobe and stone masonry buildings minimally reinforced with timber lintel beams. The masonry structures were built with regional adobe stone and wooden roof. These buildings that were built with soil mortar have partially or completely during the earthquakes (Fig. 2). Due to atmospheric conditions at time, degradation both in material and in connections can be observed. Connection between walls and roof were not observed in most structures. These buildings were constructed by 
their own residents without any engineering knowledge. The reason of the vast majority of the collapse of the gable walls is their inadequate connection to the structure and their construction with missing lintels.
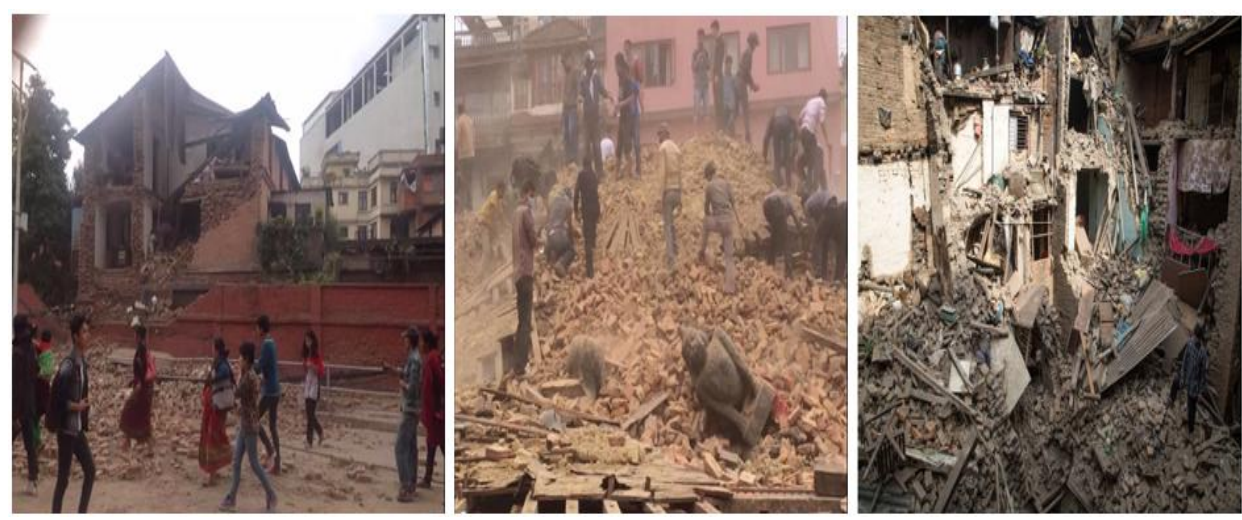

Figure 2. Damages of masonry structures

Nepal is in Katmandu Valley and this Valley in particular is very susceptible to earthquake [20]. The mud material is used as mortar in between bricks in all structures generally. Mud has very weak strength compared to the strength of brick and timber. In case of greater thrust the mud mortar cracks and helps to displace wall thus absorbing the thrust. This causes partial collapse preventing total collapse of the building. The vernacular house is made of clay, brick, timber and stone, which are very weak. Most of the old mud-mortar and stone buildings of the Kathmandu Valley are similar to those of Turkey's rural areas. The damage in Nepal was similar to damage in Turkey after earthquakes. Another widely used material in masonry structure is regional stone. The binder used in such structures is low-strength cement mortar or clay. Poor quality of this binder is one of the reasons for the structural damages in rural regions (Fig. 3).
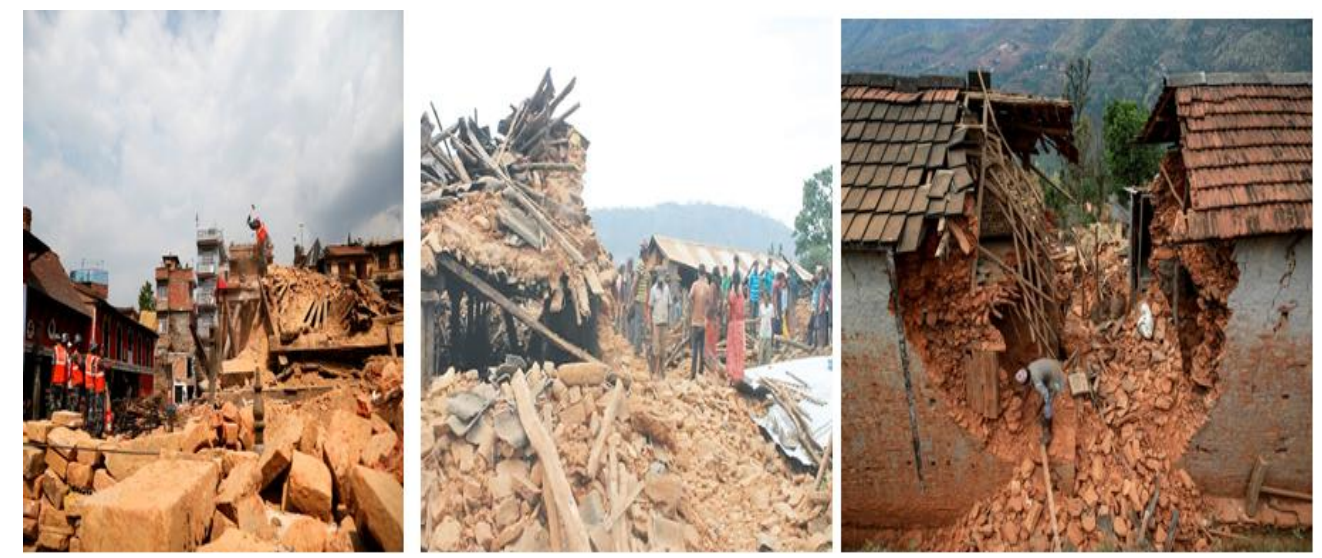

Figure 3. Damages to the poor quality of mortar in stone structures

Masonry structures compose of longitudinal walls load bearing system of which is mare of bricks, natural stones and etc. Also most of the traditional and historical buildings were constructed by masonry method. The preference reason of masonry structures were ease of building with local materials and economy. These kinds of buildings generally are built without sufficient engineering knowledge and without taking the standards into consideration. As masonry structures are made of brittle materials such as bricks and mortar, their ductility is low. Also the earthquake energy consuming capacities are lower compared to concrete buildings. Walls in masonry structures surround the usage area of the building and at the same time act as load bearers. Load transfer is between used material and mortar. The load bearing system elements of masonry buildings are composed of floors, walls that are supported by them and the foundations if these walls. Masonry structure damages generally occur as cracks on the walls, settlement of foundation and deformation or decay in the material used. Generally the tensile strength of the wall material in masonry structures are low while the shear strength of the mortar is low. Most important reason of damage is the crack and separation due to tensile strength and shear strength during earthquake. Also adherence souls be provided between materials in order to ensure healthy load transfer. 


\subsection{GEOTECHNICAL DAMAGES IN NEPAL}

Earthquakes caused secondary hazards such as landslides and rockfalls. A landslide, also known as a landslip, is a geological phenomenon that includes a wide range of ground movements. Rockfall is a kind of geotechnical damage that could be observed after earthquake. Rockfalls, deep failure of slopes and shallow debris flows were common. Landslides cause damage to transportation routes, utilities, and buildings and create travel delays and other side effects. Rockfall incidents occurred in Nepal highway and nearby slopes (Fig. 4). In order to decrease the impact of landslide and rock falls on urban and rural areas first of all it is essential to take geological hazard possibilities in to consideration and prevent construction on the terrain which carry risk and also minimize the existing risks as well. As a result, detailed mapping of the regions which are under risk of landslide and rock fall should be made as soon as possible.
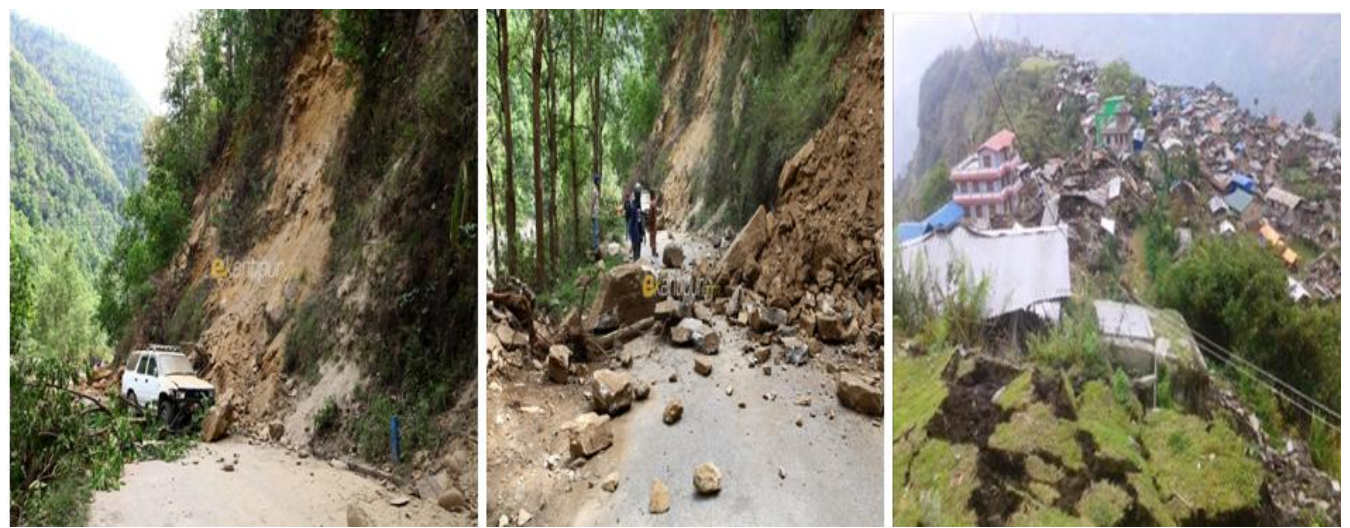

Figure 4. Rockfalls and landslides

The other damage type is foundation damage. In projecting of structure systems, it is necessary to take the interaction between structure-foundation-ground triplet into consideration and take the effects of deformations caused on ground layers due to loads transmitted to the ground on inner forces and load distribution in foundation element and superstructure load bearing system into account. While designing engineering structures structure foundation should operate in accordance with the ground as much as possible and should fulfil the design criteria in geotechnical and structural means. Ground-structure interaction is generally reduced only to resolution of foundation element. Structure-ground interaction should be a nonnegligible element of structure design. There is no damage in structural system but the building was separated from the ground. Adherence between the ground and the building is not enough (Fig.5). In a frame of a common model where ground environment, foundation type and superstructure are taken into consideration together, mutual interaction of ground and structure during earthquake should be taken into account while making the calculations.

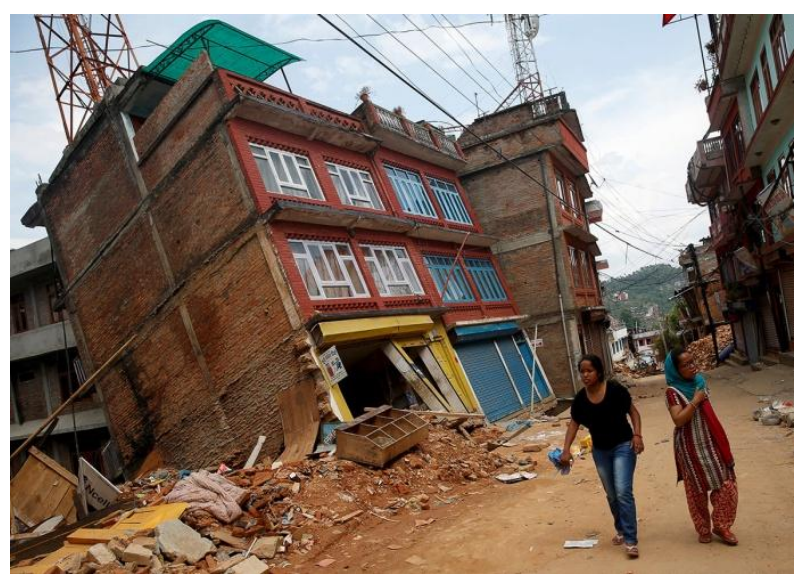

Figure 5. Foundation damage (Source: http://www.ibtimes.co.uk/nepal-buildings-lean-precariously-aftermathsecond-earthquake-photo-report-1501297)

\subsection{DAMAGES TO HISTORICAL MONUMENTS IN NEPAL}

Historical buildings also faced damages in the earthquake. There are important historical monuments in

Nepal such as temples and monasteries. Temples and monasteries constructed of heavy rocks, bricks, mudmortar, masonry, and timber, as well as individual houses built with adobe, stone, mud-mortar, brick-cement, 
and masonry having low tensile strengths is likely to be destroyed. [21]. The temples were mostly unreinforced (Fig.6).

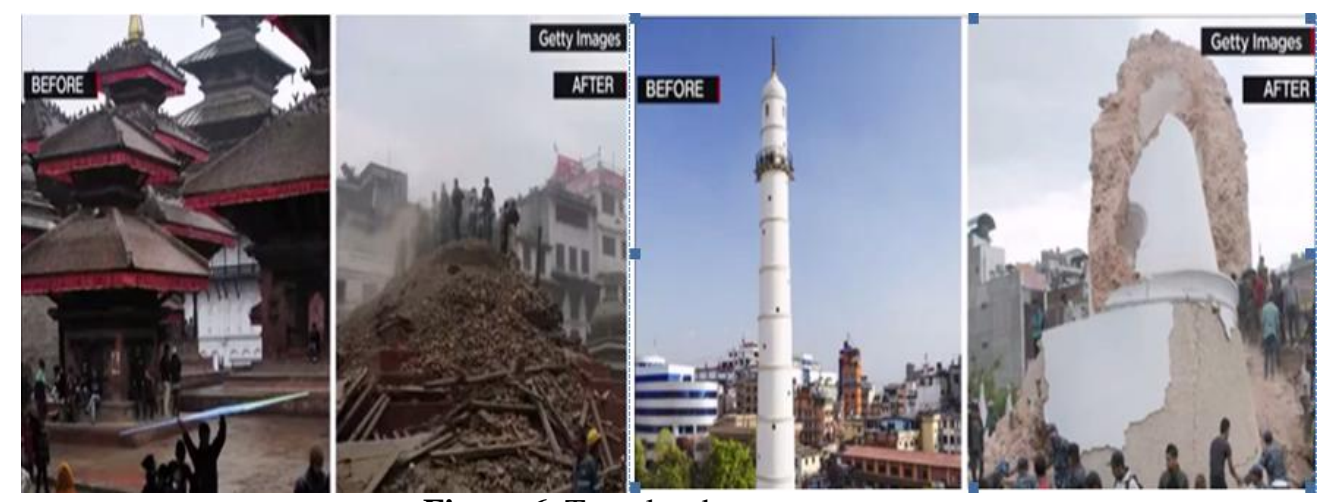

Figure 6. Temples damages

(Source: http://www.ibtimes.co.uk/nepal-buildings-lean-precariously-aftermath-second-earthquake-photoreport-1501297)

\subsection{DAMAGES TO RC BUILDINGS IN NEPAL}

$\mathrm{X}$ - shaped crack is a kind of earthquake damage in the structural walls in RC buildings. These cracks have continued to the inner of these structural walls [22]. The walls within concrete frame are generally protected by the frame. at the same time, they limit the movement of the frame and carry horizontal load. The damage which initially starts by infill wall and frame later advanced as X shaped shear cracks on high earthquake horizontal load levels. The level of the damage also depends on the story displacement rate of the structure during earthquake. This typical damage due to earthquake has also been observed in Nepal (Fig. 7). Building the walls that completely fills the frame gaps by highly resistant wall material and mortar will increase the horizontal load bearing capacity of structures.

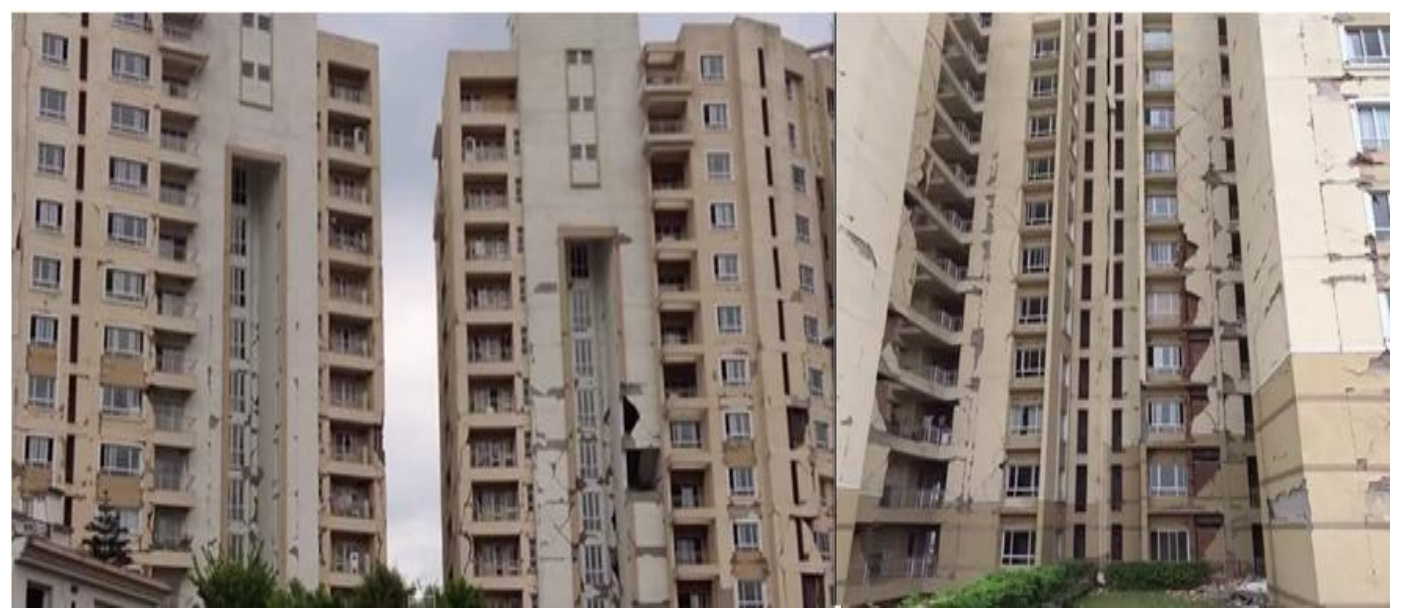

Figure 7. Walls damage

The problem of pounding is unavoidable in many large cities located in seismically active regions where, due to land usage requirements, buildings are constructed adjacent to each other. The buildings which are adjacent to each other carry a high risk because of different periods because of their different heights and weights of buildings due to the principle of conservation of energy as seen as in past earthquakes [23]. Pounding effects that occur due to earthquake forces originated by lack of dilatation gap in contiguous buildings causes this kind of buildings to take heavy damage or completely collapse under that impact. Pounding damage of adjacent buildings in Nepal is given in Fig.8. Pounding effect should be decreased in contiguous buildings by leaving proper dilatation gap. 


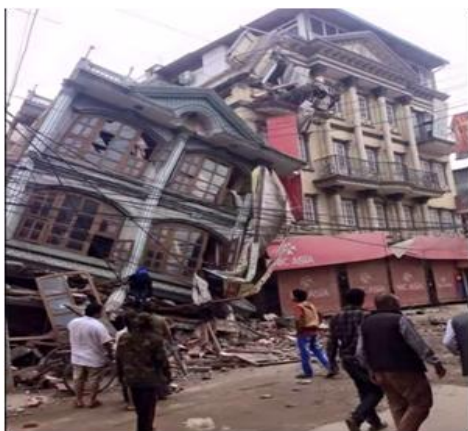

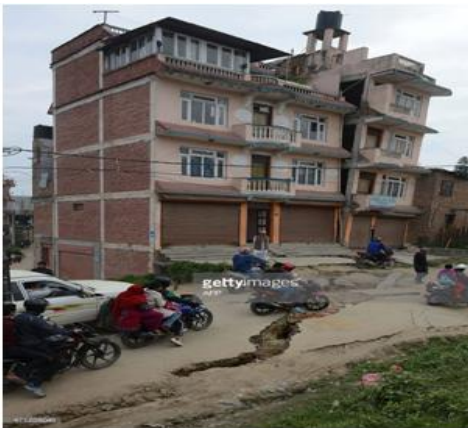

Figure 8. Pounding damages

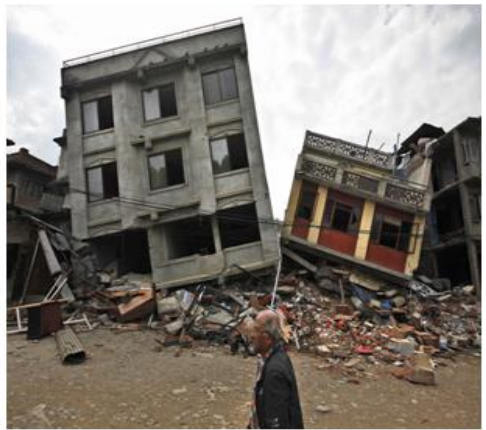

1.654075) while infill walls are intensively used in upper floors so resistance differences occur between floors. As a matter of fact although building is string by all means, these structures take heavy damage/collapse because of weak/soft storey and building collapses observed in earthquake region (Fig.9). Weak/soft storey formation should be avoided, earthquake forces should be carried by partitions and frequent stirrups should be used in each section of columns of the floors demonstrating such negative property.
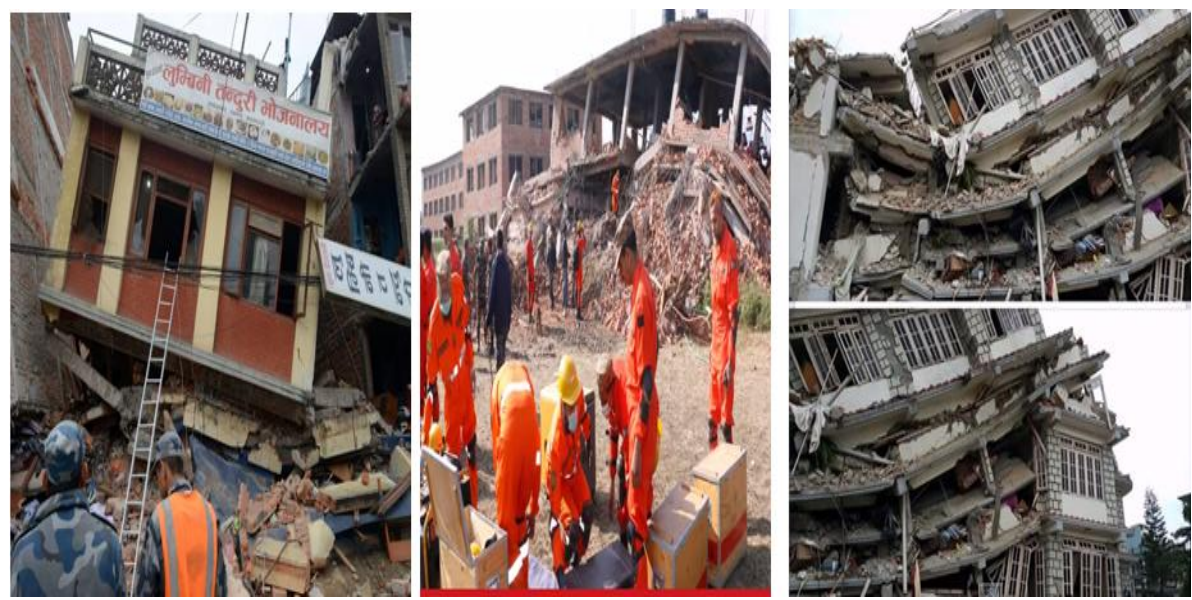

Figure 9. Weak and soft story damages

(Source: http://www.haaretz.com/israel-news/1.654075)

Frame damages are observed in columns more than the other elements of frame system in RC buildings because of columns were built weaker than beams. The reasons of much damage in columns are insufficient shear force bearing capacity of columns and inadequate adherence between concrete and reinforcement [22]. Damaged columns showed that reinforcements that were used in structural systems elements are not provided principles of regulatory of reinforcement that are given in National Codes. Especially wide spacing of the crossties related to buckling of longitudinal reinforcement. The concrete that was in the core region was diffused because of this buckling. In connection parts and column winding sections if there are not sufficient winding reinforcements, core concrete is easily smashed and longitudinal column reinforcements twist. Therefore, the column cannot bear the expected loads. Preventing the inner force distribution between elements cause decreasing in bearing element rigidity. The damages occurring in column-beam connection section are generally originated from unnecessary lateral reinforcement densification or insufficient connection of beam longitudinal reinforcements to the column. As the damage observed in connection section decreases the bearing system rigidity significantly the resistance of the system to the horizontal loads may suddenly decrease. Frame damages that observed in Nepal are given in Fig. 10. There should be no lack of connection in frame systems. Stirrup densification should be performed to column-beam cross-sections which are close to column-beam connection sections that are expected to be the most forced sections during earthquake. 


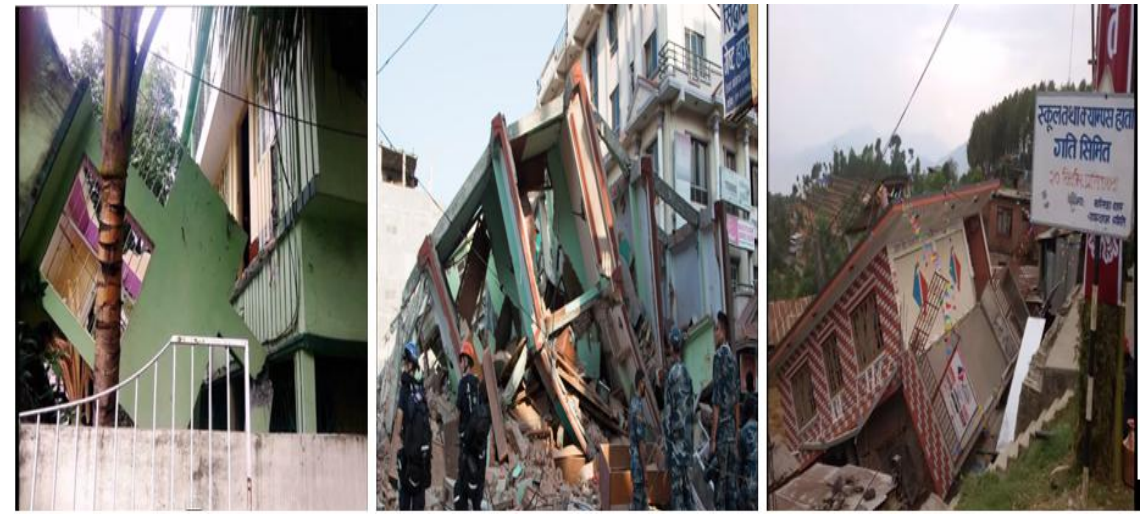

Figure 10. Damages in structural system

(Source: http://darkroom.baltimoresun.com/2015/05/second-earthquake-hits-nepal/\#1)

Furthermore, more than $98 \%$ of buildings in Nepal are up built by owners who follow the local craftsmen's advice. Eventually, most of residential buildings which are even in urban environment do not receive any rational design for strength. Hence, conventional craftsmen have a significant role despite that any specific training related to seismic safety is not provided to them and they do not have sufficient access on information about safer building practices. Additionally, even though most of municipalities do not have building permits' system, any provision is not seen in the process in order to control plans which is given against the strength criteria. Even though the building permit process was presented to them, there is insufficient institutional and technical capacity in the local authorities by means of practicing provisions related to strength. In such an explicitly difficult case, if the following cases are no taken, it can be impossible to promote safer building construction; to change the importance from training the engineers to training the masons, and to look more to convince house owners about earthquake safety rather than only to control them by the building permits' process [4]. The NBC 201 and 205 recommendations requirements in terms of reinforcement in beams and columns are not enough for high seismic demands and can lead to structures with strong-beam weak-column mechanism behaviour. The column sections resulting from a design based on the NBC code are insufficient to withstand the expected earthquake demands. Beam-column joints are not properly detailed [5]. So NBC must be improved.

\section{CONCLUSIONS}

The damage to reinforced concrete and masonry structures due to these earthquakes are presented. Searching the damage and failures for possible evidence of insufficient design code and academic knowledge was difficult. The reason for such damages and failures was not surprising according to up-to-date academic knowledge and current national design codes.Nepal is constantly under the influence of micro and macro earthquakes when examining the historical and instrumental earthquakes. Thus, it will not be difficult to say that Nepal can remain under the influence of larger earthquakes. Therefore, buildings must be constructed according to the earthquake design codes especially in Nepal. The study about seismic hazard analysis about the region that has been made by researchers was shown that Nepal is in a high risk zone. The careless selection of the design and construction of structural systems has increased the damage extent.

In this study the effects of the earthquakes on constructions in Nepal have been evaluated. The observed damages overlap with typical earthquake damages. The earthquake magnitude and the negative structural properties have given an increase in damage extent. In order to provide more significant approaches to diminish the level of damage risk which occurs after earthquakes, it will be suggested to know about the buildings' properties which have been impressed in the buildings' seismic behaviour under earthquakes. Most of the damaged buildings have not been constructed according to national earthquake codes.

The poor quality of workmanship using the low-strength local wall materials, careless of selection, design and construction of structural system, insufficient engineering services, poor connections and poor material quality and constructed buildings adjacent, using poor quality concrete, insufficient adherence between foundation and ground were caused to damage. It has been observed that very simple engineering principles in design and construction stages are ignored in the wealthy central area due to the lack of adequate control mechanism.It unfolds the necessity of earthquake effects to be kept in mind during construction. Due to seismic risks, the reality of earthquake should not be forgotten in world. Knowing the reasons of earthquakes damage is important to minimize the probable economic and life loses. Recently modern disaster management emphasized not only disaster preparedness but also the importance of disaster prevention.

Negating buildings' earthquake vulnerability means to render them more durable in the case of a possible earthquake. In this context, the importance of building designers' compliance with the provisions of the regulations concerning building design gains prominence. In addition, after the design phase it is essential to 
conduct the required and adequate controls during the actual construction of buildings. In order to ensure that a project gains both technical and scientific significance, the sensitivity shown during the construction phase should be maintained throughout the whole process of the project. The structural damage is observed to be directly proportional with the amount of the insufficient quality in the workmanship and usage of inadequate building materials. If a minimum amount of engineering attention had been paid during the construction stages, most of the existing buildings could have sustained the earthquakes without considerable damage.

Adobe and masonry buildings are very common in rural areas of Nepal because of easy workmanship and cheap construction cost. However, these buildings are always seriously affected by earthquakes as observed before. The majority of the damaged structures were seismically insufficient, unreinforced masonry and adobe buildings in rural areas. In this paper, site surveys of the damaged masonry and adobe buildings are presented and the reasons for the caused damages are discussed in detail. Engineering services should be provided for masonry buildings. Because this kind of buildings are generally made without calculating earthquake loads and without taking necessary details into consideration. The corner connections on the walls should be made properly. The wall order should not be separated from symmetry on the plan and necessary constructive rules should be followed. The subject that should be emphasized is that resistance and ductility are not independent from each other but are complementary of each other. In order to provide ductility property which is essential to prevent the building from collapsing during earthquake the structural elements which are expected to absorb great amount of energy should at the same time have enough resistance.

\section{REFERENCES}

[1] Kundak S, Türkoğlu H,(2006) "Earthquake Risk Assessment for Istanbul”, Journal of ITU, 6(2): 23-

[2] Işık, E. (2013), "The evaluation of existing buildings in Bitlis province using a visual screening method”, Süleyman Demirel Univ. J. Nat. Appl. Sci., 17(1), 173-178.

[3] Dixit AM, Krishna Y, Guragain R, (2004)“ Indigenous Skills and Practices of Earthquake Resistant Construction in Nepal", 13th World Conference on Earthquake Engineering, Vancouver, B.C., Canada.

[4] Dixit A M, (2004) "Promoting Safer Building Construction in Nepal", 13th World Conference on Earthquake Engineering, Vancouver, B.C., Canada.

[5] Chaulagain H, Rodrigues H, Spacone E, Varum H, (2012) "Reflection on the Seismic Vulnerability Associated to Common RC Buildings in Nepal" 15th World Conference on Earthquake Engineering, Lisbon, Portugal.

[6] Web Source: http://www.ngdc.noaa.gov/

[7] Ganse A R, Nelson, John B, (1981) “Catalog of Significant Earthquakes 2000 B.C.-1979”, National Geophysical and Solar-Terrestrial Data Center.

[8] Ram TD, Guoxin W, (2013) "Probabilistic Seismic Hazard Analysis in Nepal", Earthquake Engineering and Engineering Vibration, 12(4), 577-586.

[9] Bilham R, Bodin P, Jackson M, (1995) "A Great Earthquake in Western Nepal Historic in Activity and Geodetic Tests for the Present State of Strai” Journal of Nepal Geological Society, 11(1), 73-78.

[10] Chaulagain H, Rodrigues H, Spacone E, Varum H,(2013a) "Seismic Assessment of Three-Storey Residential Buildings in Nepal”, 4th International Conference on Integrity, Reliability and Failure, Funchal/Madeira

[11] Center for Disaster Management and Risk Reduction Technology (CEDIM), (2015), “Nepal Earthquakes - Report \#3"

[12] Usgs, (2015), "Poster of the Nepal Earthquake of 25 April 2015 - Magnitude 7.8"

[13] Isik, E. (2016). "Consistency of the rapid assessment method for reinforced concrete buildings". Earthquakes and Structures, , 11(5), 873-885.

[14] Chaulagain H, (2010) "Assessment of Response Reduction Factor of RC Buildings in Katmandu Valley Using Non-Linear Pushover Analysis", The Master of Engineering in Earthquake Purbanchal, University, Bhaktapur, Nepal, 136p.

[15] Chaulagain H, Rodrigues Jara J, Spacone E, Varum H,(2013b) "Seismic Response of Current RC Buildings in Nepal: A Comparative Analysis of Different Design/Construction", Engineering Structures 49(2013), 284-294.

[16] Marhatta Y B, Bothara J K, Magar M B, Chapagain G, (2007) "Pillar Walaghar (URM Infilled RC Frame Buildings)”, World Housing Encyclopedia, Report\#145

[17] Shrestha B, Dixit AM, (2008) "Standard Design for Earthquake Resistant Buildings and Aid to Building Code Implementation in Nepal", Fourteen World Conference on Earthquake Engineering, Beijing, China

[18] D'Ayala D, Bajracharya SRS, (2003)“Traditional Nawari house in Kathmandu Valley” World Housing Encyclopedia, Report\#99 
[19] Parajuli YK, Bothara JK, Upadhyay BK, (2002)“ Uncoursed Rubble Stone Masonry Walls with Timber Floor and Roof", World Housing Encyclopedia Report\#74

[20] Pradhan Riddhi (2000) "Seismicity and Traditional Buildings of Kathmandu Valley, Nepal." Proceedings of the ICOMOS International Wood Committee (IIWC), Earthquake-safe: Lessons to be Learned from Traditional Construction, International Conference on the Seismic Performance of Traditional Buildings, p.16-18.

[21] Bhattarai K, Conway D, (2010) "Urban Vulnerabilities in the Kathmandu Valley, Nepal: Visualizations of Human/Hazard Interactions”, Journal of Geographic Information System, 2010(2), 63-84.

[22] Bayülke N, (1995) "Repair and Strengthening of Structures Damaged in Earthquake", Press of IMO İzmir 255p.

[23] Bal İE, Tezcan SS, Gülay GF, (2007) "P25 Rapid Screening Method to Determine the Collapse Vulnerability of R/C Buildings", Sixth National Conference on Earthquake Engineering, Istanbul, Turkey, pp.661-674. 